\title{
DECIPHERING ROSETTA STONE: WHY THE LEAST Cost AVoider Principle Unlocks THE Code TO CONTRIBUTORY TRADEMARK INFRINGEMENT IN KEYWORD ADVERTISING
}

\author{
Sarah Wells Orrick"
}

Technological innovation will always outpace the law: it is impossible to legislate or litigate an innovation that does not yet exist. Litigating new technology becomes problematic when the harm is obvious, but existing law provides no clear remedy. The past decade has seen a flood of cases concerned with trademark infringement on the Internet. As courts struggle to apply existing trademark law, they have reached confusing and contradictory results.

This Note discusses contributory trademark infringement in the realm of keyword advertising, as highlighted in Rosetta Stone Ltd. v. Google, Inc. ${ }^{1}$ Although Rosetta Stone settled in November of 2012, the case remains significant because it directly addresses the challenges of analyzing contributory trademark infringement in a swiftly changing environment: the Internet. This Note argues that courts considering claims of contributory trademark infringement for keyword advertising should look to tort lawtrademark infringement's predecessor-for guidance.

"Keyword advertising" describes the process by which companies like Google use proprietary search algorithms to connect a searched-for word or phrase with relevant advertisements that run alongside the results of the search. ${ }^{2}$ Much of Google's revenue comes from this advertising. Advertisers purchase the space through an online auction system. ${ }^{4}$ In 2010, Rosetta Stone sued Google for allowing advertisers to bid on trademarked terms, alleging that Google's policy constituted trademark infringement. ${ }^{5}$

(C) 2013 Sarah Wells Orrick.

† J.D. Candidate, 2014, University of California, Berkeley School of Law.

1. Rosetta Stone Ltd. v. Google, Inc., 676 F.3d 144 (4th Cir. 2012) (Rosetta Stone II) aff'g in part 730 F. Supp. 2d 531 (E.D. Va. 2010) (Rosetta Stone I).

2. Id. at $150-51$.

3. Corrected Brief for eBay Inc. \& Yahoo! Inc. as Amici Curiae Supporting Appellee, Rosetta Stone Ltd. v. Google, Inc. No. 10-2007, 2010 WL 4956286, at *2.

4. Rosetta Stone II, 676 F.3d at 151.

5. Rosetta Stone I, 730 F. Supp. 2d at 531. 
Rosetta Stone comes at what may be the tail end of keyword advertising litigation. Eric Goldman, Professor of Intellectual Property at Santa Clara University Law School, recently wrote that "[] awsuits over the sales of keyword advertising seem so . . 2005." "His sentiment reflects the fact that the technology and basic structure of keyword advertising remains the same, although the cases have evolved due to changes in practices and jurisprudence. However, courts have yet to articulate a clear standard for evaluating trademark owners' claims alleging contributory infringement by a search engine.

Part I of this Note begins with an explanation of the origins of trademark law, from common law cause of action to statutory right. Next, Part II explains the basic tenets of keyword advertising and its ecosystem of players, aims, and issues. Part III of this Note discusses Rosetta Stone, focusing on Rosetta Stone's claim of contributory infringement. Lastly, Part IV demonstrates the benefit to applying the tort principle of the least cost avoider to the case at hand, arguing that Google can and has made similar accommodations in the past. $^{7}$ Google_as the least cost avoider-should take steps to fix the current situation. More broadly, courts should apply the principle of the least cost avoider in trademark law where no precedent specific to an evolving technology exists.

\section{REDISCOVERING THE ORIGINS OF TRADEMARK}

In 1982, the Supreme Court affirmed contributory trademark infringement as a cause of action in Inwood Laboratories v. Ives Laboratories. ${ }^{8}$ This was thirty-six years after passage of the Lanham Act, the most modern codification of federal trademark law. But American courts recognized harms stemming from trademark infringement long before the Lanham Act. ${ }^{9}$ In the nineteenth century, litigants brought trademark infringement claims under the torts of deception and fraud. ${ }^{10}$ The Supreme Court permitted the claim of contributory trademark infringement in 1924, well before the passage of the

6. Eric Goldman, Fourth Circuit's Rosetta Stone v. Google Opinion Pushes Back Resolution of Keyword Advertising Legality Another 5-10 Years, TECH. \& MARKETING L. Blog (Apr. 10, 2012, 7:58 AM), http://blog.ericgoldman.org/archives/2012/04/fourth_circuits.htm.

7. The least cost avoider theory holds that the party who can most cheaply prevent an accident should do so. See infra notes 113, 114.

8. Inwood Labs. v. Ives Labs., 456 U.S. 844 (1982).

9. AT\&T Co. v. Winback \& Conserve Program, Inc., 42 F.3d 1421, 1433 (3d Cir. 1994), vacating 851 F. Supp. 617 (D.N.J. 1994) (stating that the Lanham Act "generally and purposefully [comes] from the common law tort of unfair competition").

10. See id.; see also infra Section I.A. 
Lanham Act. ${ }^{11}$ The interweaving of tort and trademark law is not new, and it suggests a way to approach trademark infringement on the ever-changing Internet.

\section{A. An Evolving Area of Tort: Trademark LaW Before the LANHAM ACT}

The Founding Fathers recognized the need for patent and copyright protection, authorizing Congress to create protection for these rights in the Constitution. ${ }^{12}$ Not so for trademark. ${ }^{13}$ Early trademark infringement cases specified deception and fraud as the causes of action: how a person perpetrated the fraud mattered less. Cases such as Coats v. Holbrook ${ }^{14}$ and Partridge v. Menck ${ }^{15}$ feature what today would be considered classic trademark infringement fact patterns: one competitor copied the mark or product that another had established. At the time, the New York Court of Chancery characterized this harm as deception, a common early approach to trademark infringement. ${ }^{16}$ Most nineteenth century cases were restricted to "prevent[ing] competitors from dishonestly diverting customers who otherwise would have gone to the senior user of a mark." 17 Similarly, the class of potential infringers was smaller: "[s]pecifically, a trademark owner was entitled to relief only against competitors that dishonestly marked their products and passed them off as those of the mark owner." trademark protection was narrower than it is today, but well established. ${ }^{19}$

Statutory protection came late to trademark. In 1870, Congress passed the Trademark Law, contending that the Copyright Clause of the Constitution provided for congressional oversight of trademarks. ${ }^{20}$ The

11. William R. Warner \& Co. v. Eli Lilly \& Co., 265 U.S. 526 (1924).

12. See U.S. CONST. art. I, $\int 8$, cl. 8 ("The Congress shall have power . . . To promote the Progress of Science and useful Arts, by securing for limited Times to Authors and Inventors the exclusive Right to their respective Writings and Discoveries.").

13. Id. Note that although the Constitution does not explicitly delineate trademark as a right that may be protected by Congress, other parts of the Constitution, such as the Commerce Clause, give Congress the power to oversee trademarks. See U.S. CONST. art. I, $\int 8, \mathrm{cl} .3$.

14. Coats v. Holbrook, Nelson \& Co., 2 Sand. Ch. 586 (N.Y. Ch. 1845) (holding that one person who intended to "attract to himself the patronage that without such deceptive use of such names ... would have inured to the benefit of that other person").

15. Partridge v. Menck, 2 Barb. Ch. 101 (N.Y. Ch. 1847).

16. Coats, 2 Sand. Ch. at 594.

17. Mark P. McKenna, The Normative Foundations of Trademark Law, 82 NOTRE DAME L. REV. 1839, 1843 (2007).

18. Id. at 1848 .

19. See id. at 1859-60.

20. In re Trade-Mark Cases, 100 U.S. 82 (1879). 
Supreme Court disagreed, striking down the law in a set of decisions known as the Trade-Mark Cases. ${ }^{21}$ Congress retaliated by passing a second trademark law in 1881, this time based on the Commerce Clause and more limited in scope. $^{22}$

Despite Congressional attempts to provide statutory protection for trademarks, in the late nineteenth and early twentieth centuries, trademark claims were still litigated as torts. Courts considered trademark claims a form of fraud and unfair competition. ${ }^{23}$ Oliver R. Mitchell wrote in the Harvard Law Review in 1896, "[1] ogically speaking, the fact is that Unfair Competition is properly a generic title, of which trade mark is a specific division." 24 The Sixth Circuit echoed this sentiment, holding, "[t] he entire substantive law of trade-marks . . . is a branch of the broader law of unfair competition." 25

As tort law swelled to encompass contributory liability, common law trademark claims expanded to include contributory trademark infringement. In William R. Warner \& Co. v. Eli Lilly \& Co., the Supreme Court explained contributory trademark infringement as a species of tort, ${ }^{26}$ holding that "[o]ne who induces another to commit a fraud and furnishes the means of consummating it is equally guilty and liable for the injury." 27 The Court's language gave rise to a line of cases standing for the proposition that a party who did not directly infringe a trademark could be liable for the direct infringer's actions in certain circumstances. ${ }^{28}$ Between 1924 and 1946, multiple courts permitted contributory infringement claims in trademark disputes. $^{29}$

21. Robert P. Merges, Peter S. Menell, and Mark A. Lemley, Intellectual Property IN THE NEW TECHNOLOGICAL AgE 764 (6th ed. 2012).

22. See id.

23. Frischer \& Co. v. Bakelite Corp., 39 F.2d 247, 268 (C.C.P.A. 1930) (explaining that " $[\mathrm{t}]$ rade-mark infringement, when found by the courts, enters into the law of unfair competition"); see also MERGES, supra note 21, at 765 (stating that "the fundamental principles of trademark law have essentially been ones of tort: unfair competition and the tort of deception of the consumer").

24. Oliver R. Mitchell, Unfair Competition, 10 HARV. L. REV. 275, 275 (1896). But note that Mitchell then explains that trademark law had developed earlier than the specific type of "unfair competition" that was then new.

25. G. \& C. Merriam Co. v. Saalfield, 198 F. 369, 373 (6th Cir. 1912).

26. William R. Warner \& Co. v. Eli Lilly \& Co., 265 U.S. 526 (1924); see also John T. Cross, Contributory Infringement And Related Theories Of Secondary Liability For Trademark Infringement. 80 IOWA L. REV. 101, n.1 (2008).

27. Warner, 265 U.S. at 530-31 (citing Hostetter Co. v. Brueggeman-Reinert Distilling Co., 46 F. 188 (E.D. Mo. 1891)).

28. Cross, supra note 26, at 101.

29. See, e.g., Smiling Irishman, Inc. v. Juliano, 45 N.Y.S.2d 361, 369 (Sup. Ct. 1943); Irwin v. Fed. Trade Comm'n, 143 F.2d 316, 325 (8th Cir. 1944); Champion Spark Plug Co. v. 


\section{B. MODERN TRADEMARK LAW}

Although Congress had previously considered tort law sufficient protection for trademark owners and consumers, legislators realized the need for codification of existing law by the mid-1940s. ${ }^{30}$ The expansion of the American economy and increased mobility of the average American had largely erased local geographic distinctions. As a result, businesses that once peacefully co-existed became fierce rivals for overlapping territory. Only a strong federal law could place those in all states on an equal playing field.

Congress enacted the Lanham Act in 1946 to codify a federal trademark law, drawing heavily from existing common law. In doing so, legislators imported the tort principles that were already woven into trademark common law. For example, $\int 1114$ of the Lanham Act codified contributory trademark infringement as a cause of action:

15 U.S.C.A. \1114. Remedies; infringement; innocent infringement by printers and publishers

(1) Any person who shall, without the consent of the registrant-

(a) use in commerce any reproduction, counterfeit, copy, or colorable imitation of a registered mark in connection with the sale, offering for sale, distribution, or advertising of any goods or services on or in connection with which such use is likely to cause confusion, or to cause mistake, or to deceive; or

(b) reproduce, counterfeit, copy, or colorably imitate a registered mark and apply such reproduction, counterfeit, copy, or colorable imitation to labels, signs, prints, packages, wrappers, receptacles or advertisements intended to be used in commerce upon or in connection with the sale, offering for sale, distribution, or advertising of goods or services on or in connection with which such use is likely to cause confusion, or to cause mistake, or to deceive,

shall be liable in a civil action by the registrant for the remedies hereinafter provided. Under subsection (b) hereof, the registrant shall not be entitled to recover profits or damages unless the acts

Emener, 16 F. Supp. 816 (E.D. Mich. 1936); Chesebrough Mfg. Co. v. Old Gold Chem. Co., 70 F.2d 383, 385 (6th Cir. 1934). Note that not all courts found that contributory infringement had occurred in each case: they merely accepted that it was an actionable claim in the abstract.

30. See S. Rep. No. 1333, 79th Cong., 2d Sess. 3 (1946), reprinted in 1946 U.S. Code Cong. Serv. 1274, 1275 ("However, trade is no longer local, but is national. Marks used in interstate commerce are properly the subject of Federal regulation. It would seem as if national legislation along national lines securing to the owners of trade-marks in interstate commerce definite rights should be enacted and should be enacted now.'). 
have been committed with knowledge that such imitation is intended to be used to cause confusion, or to cause mistake, or to deceive. $^{31}$

The statute does not explain how to identify contributory trademark infringement or how to analyze or resolve such cases. The corresponding legislative history, however, stated that the "present bill preserves the things which have demonstrated their usefulness," 32 so lower courts looked to trademark precedent that predated the Lanham Act to interpret the statute. ${ }^{33}$

The Supreme Court did not rule on contributory trademark infringement until Inwood Labs in 1982. ${ }^{34}$ Inwood Labs presented a fairly straightforward contributory trademark infringement case, not unlike Warner. Inwood Laboratories, a pharmaceutical manufacturer, discovered that pharmacists were substituting a generic, identical-looking pill for Inwood's more expensive original, Cyclospasmol. ${ }^{35}$ Instead of filing suit against individual pharmacists, Inwood sued the creator of the generic pill for trademark infringement. ${ }^{36}$ The Supreme Court held that "liability for trademark infringement can extend beyond those who actually mislabel goods with the mark of another." 37 In so holding, the Court recognized contributory trademark infringement as a cause of action:

As the lower courts correctly discerned .... if a manufacturer or distributor intentionally induces another to infringe a trademark, or if it continues to supply its product to one whom it knows or has reason to know is engaging in trademark infringement, the manufacturer or distributor is contributorially responsible for any harm done as a result of the deceit. ${ }^{38}$

The Court also created a two-part test for contributory trademark infringement. ${ }^{39}$ To meet the standard for contributory trademark infringement, the party must have either (1) intentionally induced trademark

31. 15 U.S.C. $\int 1114$ (2006).

32. See S. Rep. 1333, supra note 30.

33. See Cross, supra note 26, at 101. See, e.g., SK \& F, Co. v. Premo Pharm. Lab., Inc., 625 F.2d 1055 (3d Cir. 1980); Upjohn Co. v. Schwartz, 246 F.2d 254 (2d Cir. 1957); Teledyne Indus., Inc. v. Windmere Prods., Inc., 433 F. Supp. 710 (S.D. Fla. 1977); Mattel, Inc. v. Goldberger Doll Mfg. Co., 200 F. Supp. 517 (E.D.N.Y. 1961); Coca-Cola Co. v. Snow Crest Beverages, Inc., 64 F. Supp. 980. (D. Mass. 1946), aff'd, 162 F.2d 280 (1st Cir.), cert. denied, 332 U.S. 809, reh'g denied, 332 U.S. 832 (1947).

34. Inwood Labs, 456 U.S. 844 (1982).

35. Id.

36. Id. at $847-48$.

37. Id. at 853 .

38. Id. at 853-54.

39. Id. at 854 . 
infringement or (2) knew or should have known that it was supplying products to a party infringing another's trademark. ${ }^{40}$ The Inwood Labs test remains the standard today.

Trademark owners continue to litigate contributory trademark infringement. However, courts consistently struggle to assess contributory trademark infringement as applied to new technologies. The rate of change of the Internet and technology outdistances even the quickest conception, creation, and passage of a federal law; further, the common law application of precedent regarding previous technology does not always provide the best remedy.

\section{THE KEY IS IN THE WORDS: WHY KEYWORD ADVERTISING PRESENTS A NEW SET OF PROBLEMS, AND HOW TRADEMARK OWNERS RESPOND}

Most search engines profit not from charging users per search, but from selling advertising space that runs alongside search results. ${ }^{41}$ In the early days of search engines, websites sold advertising space without regard for the content of the user's search. Most search engines now employ keyword advertising, where the search term that the user enters will "trigger" which advertisements to display. ${ }^{42}$ Google's AdWords program is typical of the revenue structure of a search engine. Google auctions space according to an advertiser's bid: the highest bid on a specific search term generally receives the most valuable placement, and lower bids receive less preferential placement. ${ }^{43}$ The bid denotes the amount that the advertiser will pay Google each time a user clicks on the advertisement, or "cost-per-click." Google only benefits if a user finds an advertisement relevant, Google has a vested interest in providing a high volume of highly targeted advertising. ${ }^{45}$

40. Id.

41. Corrected Brief for eBay Inc. \& Yahoo! Inc. as Amici Curiae Supporting Appellee, supra note 3 , at $* 2$.

42. Rosetta Stone II, 676 F.3d 144, 150-51 (4th Cir. 2012).

43. Id. at 151. For example, a company that sells widgets might want its advertisement to show up when a person searches "where to buy widgets?" Thus, the company would bid on the phrase "where to buy widgets?" However, there may be many widget companies that might want to purchase those terms. Note that if the advertisement is irrelevant to the search term, even the highest bid might not receive top placement.

44. Id. In the example in the previous footnote, anyone who wants his ad to appear when the phrase "where to buy widgets" appears can bid on that term. The relevant highest bid will be featured at the top of the page, the next-highest bid will be slightly lower, et cetera.

45. Id. 
Since creating AdWords, Google has changed two significant policies regarding trademark use. ${ }^{46}$ In 2004, Google permitted any interested party to bid on a trademark as a triggering search term, regardless of whether the bidding party owned the trademark in question. ${ }^{47}$ For example, the change would have allowed Nordstrom to bid on the term "Neiman Marcus" to trigger advertisements for Nordstrom: when a user searched for "Neiman Marcus," advertisements for Nordstrom, among others, would appear. Such micro-targeting appeals to cost-conscious advertisers since consumers searching for one company are likely to be interested in their competitors. Allowing bids on trademarks increases the number of potential bidders. The higher the number of bidders, the greater the competition for search terms. The resulting higher-priced bids increase Google's revenue. ${ }^{48}$ To aid advertisers, Google's program suggests related terms based on an advertiser's initial trigger terms, including trademarks. ${ }^{49}$ The second change came in 2009, when Google altered its policy on the permitted content of advertisements, allowing advertisers to use trademarks in the text of their advertisements, again regardless of who owned the trademark. ${ }^{50}$

These two changes made it harder for trademark owners to guard the use of their marks. ${ }^{51}$ Now, instead of policing brick-and-mortar establishments or small stands on Manhattan's Canal Street, ${ }^{52}$ trademark owners must also comb the Internet for infringing advertisements. ${ }^{53}$ The challenges inherent in searching for trademark infringement on the Internet are different than the challenges of searching for it on the street. It is easier to infringe a trademark on the Internet. It is cheap to set up a website and use Google's AdWords

46. Id.

47. Id.

48. See GoOGLE'S KEYwORDS TOOL, https://adwords.google.com/o/Targeting/ Explorer?_c $=1000000000 \& \_u=1000000000 \&$ ideaRequest $T y p e=$ KEYWORD_IDEAS (last visited Jan. 23, 2012).

49. See id.

50. Rosetta Stone II, 676 F.3d at 151-52.

51. A fact that Google's amici point out. See Corrected Brief for eBay Inc. \& Yahoo! Inc. as Amici Curiae Supporting Appellee, supra note 3, at*3.

52. Canal Street is well known as a location for purchasing counterfeit handbags. Willy Staley, The Bag Men of Chinatown, N.Y. Times' The SiXTH Floor Blog (Feb. 8, 2013, 10:05am), http://6thfloor.blogs.nytimes.com/2013/02/08/the-bag-men-of-chinatown/. The problem is not limited to Manhattan: in Los Angeles, Santee Street, among others, provides a similar experience. See Shan Lee, Counterfeit Gap joins the counterfeit Gucci, L.A. TIMES, (Feb. 3, 2012), http:/ / articles.latimes.com/2012/feb/03/business/la-fi-cheap-fakes-20120204.

53. A fact that Rosetta Stone's amici curiae point out. See Brief for Convatec et al. as Amici Curiae Supporting Appellant at *2, Rosetta Stone II, 676 F.3d 144 (No. 10-2007), 2010 WL 4306013; Brief for Volunteers of America, Inc. as Amicus Curiae Supporting Appellant at *4-5, Rosetta Stone II, 676 F.3d 144 (No. 10-2007), 2010 WL 4317118. 
program to readily profit from trademark infringement or piracy. ${ }^{54}$ Rosetta Stone was one such victim. Rosetta Stone found advertisements on Google promoting counterfeit Rosetta Stone software. ${ }^{55}$ The pirates used the Rosetta Stone trademark to lure customers because there was no powerful check restricting trademark use. Google's changes decreased trademark owner control of marks, and increased the instances of trademark infringement in advertisements on Google's search pages.

Keyword advertising is one of several areas of the Internet particularly prone to contributory trademark infringement. Trademark owners have responded to these situations in two ways. In some instances, trademark owners sued the individual actors who infringed their marks. ${ }^{56}$ In others, trademark owners sued the search engines and other entities that facilitated the individual infringements. ${ }^{57}$

Trademark owners sue individual actors when a discrete group of actors has infringed a trademark, as in Hearts on Fire v. Blue Nile. ${ }^{58}$ Hearts on Fire, the trademark owner, sued Blue Nile, a quasi-competitor in the diamond supply business, for bidding on Hearts on Fire's trademark, "hearts on fire," as a trigger for keyword advertising, and for using the mark in the text of keyword advertisements. ${ }^{59}$ The company feared that Blue Nile's sale of diamond jewelry to consumers would confuse and mislead consumers to Hearts on Fire's detriment. ${ }^{60}$ Because Hearts on Fire only wanted to stop Blue Nile's infringement, the company could-and did-sue Blue Nile directly. Hearts on Fire had no need to sue Google to stop Blue Nile, and doing so would have been an indirect and expensive way to achieve this goal.

Where there are unknown or numerous infringers, trademark owners have sued search engines instead of individual actors. ${ }^{61} \mathrm{~A}$ review of these

54. First Amended Complaint at 1 2, Rosetta Stone II, 676 F.3d 144 (No. 10-2007), 2010 WL 835474.

55. Id. $ๆ 31$.

56. See infra note 58 .

57. See infra note 61 .

58. See, e.g., Brookfield v. W. Coast Entm't, 174 F.3d 1036 (9th Cir. 1999); Savin Corp. v. Savin Group, 391 F.3d 439 (2d Cir. 2004); Australian Gold v. Hatfield, 436 F.3d 1228 (10th Cir. 2006); Hearts on Fire v. Blue Nile, 603 F. Supp. 2d 274 (D. Mass. 2009).

59. Hearts on Fire, 603 F. Supp. 2d at 278-79.

60. Id.

61. See, e.g., Lockheed Martin Corp. v. Network Solutions, Inc., 194 F.3d 980 (9th Cir. 1999); Playboy Enters. v. Netscape Commc'ns Corp., 354 F.3d 1020 (9th Cir. 2004); Gov't Emps. Ins. Co. v. Google, Inc., 330 F. Supp. 2d 700 (E.D. Va. 2004); 800-JR Cigar, Inc. v. GoTo.com, Inc., 437 F. Supp. 2d 273 (D.N.J. 2006); 1-800 Contacts, Inc. v. WhenU.Com, Inc., 414 F.3d 400 (2d Cir. 2005); Google Inc. v. Am. Blind \& Wallpaper, C 03-5340JF(RS), 2007 WL 1159950 (N.D. Cal. Apr. 18, 2007); Tiffany Inc. v. eBay Inc., 600 F.3d 93 (2d Cir. 
cases illustrates that for these plaintiffs, ferreting out the infringers might have transformed into a high-stakes game of Whac-A-Mole: expending copious resources on multiple cases without an end in sight. Just as the trademark owner had identified and stopped one infringer, another would pop up. Instead, trademark owners focused on the common denominator: the entity facilitating infringement. As with a Hi-Striker carnival game, the outcome depends entirely on a single blow.

Tiffany $^{62}$ is one such example of this Hi-Striker strategy. Famed luxury jeweler Tiffany filed suit against eBay, a large online auction site, alleging contributory trademark infringement. ${ }^{63}$ eBay both passively allows users to post items and actively promotes categories of these items through paid advertising. ${ }^{64}$ Tiffany asserted that permitting sale of secondhand Tiffany items and advertising the availability of these products constituted contributory trademark infringement because eBay knew that some of the products were likely counterfeit. ${ }^{65}$ The Second Circuit found for eBay, holding that Tiffany could not control the market for its goods after they had been sold, even if counterfeit items riddled the market. ${ }^{66}$

The Second Circuit used the test from Inwood Labs to determine whether eBay was "culpably facilitating the infringing conduct of the counterfeiting vendors." ${ }^{67}$ Because Tiffany did not contest the first prong of the Inwood Labs test, the Second Circuit focused on the second prong, whether eBay "continue[d] to supply its [service] to one whom it [knew] or had reason to know [was] engaging in trademark infringement." 68 Tiffany argued that eBay knew or had reason to know it was liable for trademark infringement, since "counterfeit Tiffany goods were being sold ubiquitously on its website." "99 The district court found that eBay had only "generalized notice that some

2010); Rescuecom Corp. v. Google, Inc., 562 F.3d 123 (2d Cir. 2009). Note that these cases were litigated at the same time as the cases against individual infringers, and do not illustrate a shift in litigation strategy. Courts considered different factors in these cases-for example, American Blind partially turned on the distinctiveness of the mark in question, while Rescuecom was primarily concerned with the definition of "use in commerce."

62. Tiffany, 600 F.3d at 93.

63. Id.

64. Id. at 97, 101.

65. Id. at 101 .

66. Id. at 97 .

67. Id. at 103. As explained in Part I, the two prongs of the Inwood Labs test ask whether the party either (1) intentionally induced trademark infringement or (2) knew or should have known that it was supplying products to a party infringing another's trademark. Inwood Labs. v. Ives Labs., 456 U.S. 844, 854 (1982).

68. Tiffany, 600 F.3d at 106 (quoting Inwood Labs., 456 U.S. at 854).

69. Id. at 106. 
portion of the Tiffany goods ... might be counterfeit." ${ }^{, 70}$ The Inwood Labs test, the court concluded, "explicitly imposes contributory liability on a defendant who 'continues to supply . . . to one who it knows or has reason to know is engaging in trademark infringement." ",71 The court reasoned that eBay "consistently took steps to improve its technology and develop antifraud measures as such measures became technologically feasible and reasonably available," ${ }^{, 72}$ including creating tools to detect fraudulent postings, promptly removing listings that Tiffany found fraudulent, and allowing Tiffany several hours to preview listings before they went live. ${ }^{73}$ Therefore, eBay was only liable for those postings that Tiffany or eBay's internal program explicitly marked as fraudulent. Tiffany's argument that the number of fraudulent postings should trigger liability for every Tiffany-related posting was, the Second Circuit concluded, an overbroad reading of Inwood Labs, and such information did not create constructive knowledge on the part of eBay. $^{74}$

The interplay between the three actors in this environment-the trademark owner, the immediate infringer, and the facilitator-was present when Rosetta Stone filed a complaint against Google in 2010.

\section{IT'S ALL GREEK TO ME: MISUNDERSTANDING A NEW TECHNOLOGY CONFOUNDED THE DISTRICT COURT IN ROSETTA STONE}

Rosetta Stone creates the most popular language-learning software on the market, offering multiple levels of over thirty different language programs. ${ }^{75}$ Rosetta Stone dominates its competition both in sales and in recognition. According to one consumer survey, seventy-four percent of consumers recognized Rosetta Stone, while twenty-three percent recognized its closest competitor. $^{76}$ As a product that must be purchased to be experienced, Rosetta Stone relies on the strength of its brand and quality of its product to move sales. Rosetta Stone has advertised with Google since 2002. ${ }^{77}$ Because

70. Id.

71. Id. at 107 .

72. Id. at 100 .

73. Id. at $99-100$.

74. Id. at 107-08. The Second Circuit also rejected the arguments of Tiffany and amici that this ruling would encourage eBay to practice willful blindness, contending that private market forces would be sufficient to keep eBay honest. Id. at 109-10.

75. Rosetta Stone II, 676 F.3d 144, 150 (4th Cir. 2012); First Amended Complaint, supra note 54, ๆ 14.

76. Rosetta Stone II, 676 F.3d at n.2.

77. Id. at 150 . 
its products are both relatively expensive and cost-efficient to duplicate, Rosetta Stone has become a popular target for software pirates. ${ }^{78}$ The pirates and copy-makers also advertise their illicit copies with Google. ${ }^{79}$ As a result of these advertisements, consumers confuse shoddy, counterfeit products with the genuine product, and sometimes purchase the counterfeit item based on this confusion. ${ }^{80}$ Rosetta Stone cannot feasibly track every infringing ad and litigate against every pirate: it would have to expend an enormous amount of resources to do so. Instead, Rosetta Stone sued Google.

Rosetta Stone alleged that Google's AdWords tool should not have suggested or permitted Rosetta Stone's trademarks to be used either as triggers for advertisements or in the text of advertisements. ${ }^{81}$ Rosetta Stone filed five claims: trademark infringement, contributory trademark infringement, vicarious trademark infringement, trademark dilution, and unjust enrichment. ${ }^{82}$ Rosetta Stone's claim for contributory infringement regarded "the infringing use of the Rosetta Stone Marks by the third-party advertisers who use the Rosetta Stone Marks to trigger the display of 'Sponsored Links.' ",83 Google denied encouraging or having reason to know of infringing use of third-party advertisers. ${ }^{84}$

The Eastern District of Virginia found for Google on Rosetta Stone's five claims in summary judgment. ${ }^{85}$ The Fourth Circuit affirmed the district court's dismissal for two of Rosetta Stone's claims, but remanded the remaining three (direct infringement, trademark dilution, and contributory infringement). ${ }^{86}$ The case settled in early November of $2012,{ }^{87}$ but remains worthy of examination because it illustrates the problems inherent in applying trademark law to new technology.

78. First Amended Complaint, supra note 54, ๆף 105, 122.

79. See supra notes $54-55$.

80. Rosetta Stone II, 676 F.3d at 156-58.

81. First Amended Complaint, supra note 54, 16.

82. Rosetta Stone II, 676 F.3d at 149.

83. First Amended Complaint, supra note 54, 185.

84. Def.'s Mem. Supp. Mot. Summ. J. at *12, Rosetta Stone II, 676 F.3d 144 (No. 102007) 2010 WL 1404259.

85. Rosetta Stone I, 730 F. Supp. 2d 531, 552 (E.D. Va. 2010).

86. Rosetta Stone II, 676 F.3d at 173.

87. Joe Mullin, Google settles Rosetta Stone lawsuit, its last major dispute over AdWords, ARS TECHNICA (Nov. 1, 2012, 10:35 AM), http://arstechnica.com/tech-policy/2012/11/googlesettles-rosetta-stone-lawsuit-its-last-major-dispute-over-adwords/. 


\section{A. The District Court Decision}

The district court considered trademark doctrine, precedent, and realworld analogy-traditional and accepted ways of judicial reasoning in trademark cases. But it failed to grasp the essence of the dispute. The district court compared Google's trademark infringement mitigation methods with eBay's mitigation methods in Tiffany and found them sufficiently similar. ${ }^{88}$ Yet, at summary judgment, it was inappropriate for the court to make such a finding of fact. The court also misapplied the doctrine of functionality, belying its misunderstanding of the purpose of the doctrine. ${ }^{89}$ The district court's most problematic pronouncements, however, stemmed from misunderstanding keyword advertising.

The district court compared Google's activity to that of billboard owners in Times Square. ${ }^{90}$ In doing so, the court illustrated its fundamental inability to grasp the nature of the dispute between Google and Rosetta Stone. The court concluded,

Given Times Square's high pedestrian and vehicular traffic, billboards located there offer advertisers great visibility, just as Google's popular search engine offers third party advertisers a great opportunity to display their advertisements for goods and services. Aside from their location and size, advertisement by billboards also allows creative 'customizing' through extensions and embellishments, a feature similar to a third party advertiser's ability to create the content of their Sponsored Link on Google's website. ${ }^{91}$

This analogy misses the mark. Advertisers purchase billboards based on the local population demographics, in addition to the physical location of the billboard. ${ }^{92}$ This is similarly true for the advertisements that appear on Google's search pages. In both media, advertisers will likely reach more people than are interested in the product. It is not against the law for Lowe's to post billboards directly next to a Home Depot store, or for Lowe's to post billboards directly next to all Home Depot billboards. However, Lowe's, in this example, would not be basing its decisions on where the Home Depot trademark appeared, but instead on where Home Depot had visibly

88. Rosetta Stone I, 730 F. Supp. 2d at 548-49 (comparing Google's actions to eBay's as described in Tiffany Inc. v. eBay Inc., 600 F.3d 93, 98-100 (2d Cir. 2010)).

89. Id. at $545-46$.

90. Id. at 550 .

91. Id.

92. See Outdoor Advertising \& Billboard Advertising Costs, CBSOUTDOOR.COM, https://www.cbsoutdoor.com/outdoor101/rates.aspx (last visited Feb. 22, 2013). 
expended its resources, either in advertising or in a store location. Lowe's would be using the actions of Home Depot to inform its decisions, not incorporating Home Depot's trademark as a means of implementing its decisions. In contrast, a trademark keyword triggers an advertisement on Google AdWords: not only does the advertiser not need to pay until the advertising succeeds, but the advertisement only appears because an internet user's search query included the trademark. The underlying cause is different.

The court also held that the content of the billboard is within the purview of the advertiser, equating it to the content of the advertisement's text, which misleads. ${ }^{93}$ Rosetta Stone did not contend that advertisements on Google should not have text or be customized, but that the text should not infringe on its trademark. The same argument against trademark infringement could be made against billboards, and, in fact, has been madethough not successfully. ${ }^{94}$ Further, there is very limited space in Times Square to display advertisements. The Internet essentially contains unlimited space. Thus, the analogy of a billboard in Times Square is inaccurate and inappropriately describes the disagreement between Google and Rosetta Stone.

\section{B. THE FOURTH CIRCUIT OPINION}

The Fourth Circuit partially affirmed the district court's findings. It upheld the district court's opinion as to the dismissal of Rosetta Stone's claims of vicarious infringement and unjust enrichment, but vacated and remanded the opinion as to the dismissal of direct infringement, contributory infringement, and dilution. ${ }^{95}$ The Fourth Circuit held that the district court's reliance on Tiffany was inappropriate at this juncture. ${ }^{96}$ However, it did not fault the district court for embarking on that analysis.

The Fourth Circuit's decision does not foreclose the possibility that Google's current AdWords policy constitutes trademark infringement. Although this case has settled, at least one author has argued that Google will likely continue to face similar lawsuits from other companies until it changes its trademark policy or receives a significant legal victory. ${ }^{97}$ The Fourth Circuit's willingness to entertain these claims puts Google in an unenviable

93. Rosetta Stone I, 730 F. Supp. 2d at 550.

94. See Mike Masnick, Legal Fight Over Billboards About Trademarks On The Hotness Of Your Wife, TECHDIRT (Jan. 25, 2010, 10:38 AM), http://www.techdirt.com/articles/ 20100113/2330097747.shtml.

95. Rosetta Stone II, 676 F.3d 144, 149-50 (4th Cir. 2012).

96. Id.

97. See Goldman, supra note 6. 
position: without a firm rejection of the possibility that the AdWords policy does constitute infringement, Google may remain the target of litigation. ${ }^{98}$

Where courts struggle to apply a law, they look to the statute, legislative history, and precedent. Here, the statute, legislative history, and precedent are of little help. One scholar contends that "courts [are] struggling with an unruly body of law that offers little guidance in confronting issues surrounding new technologies that are capable of facilitating mass infringement of copyrights and trademarks." "99 However, the Fourth Circuit pointed out that "[c]ontributory infringement is a judicially created doctrine that derive[s] from the common law of torts." 100 Additionally, the Fourth Circuit's decision did not fault the district court's reasoning but, rather, the incorrect standard that it applied.

Although recent contributory infringement cases do not offer precedent that is factually identical, they offer a framework for evaluating these cases. That framework is the least cost avoider.

\section{TRANSLATING THE CODE: HOW THE LEAST COST AVOIDER BRIDGES THE GAP FROM PROBLEM TO SOLUTION}

As shown in Part III, supra, the district court struggled to apply precedent, illustrating the difficulty courts face when technology evolves ahead of the machinery of the law. Instead of trying to determine which realworld scenario fit closest, the court ought to have hewed to an older principle:

[when] it is not clear how the doctrine applies to people who do not actually manufacture or distribute the good that is ultimately palmed off as made by someone else[,] ... we have treated trademark infringement as a species of tort and have turned to the common law to guide our inquiry into the appropriate boundaries of liability. ${ }^{101}$

If trademark is already treated as a tort, courts should apply the least cost avoider principle to solve the identified problem.

98. Eric Goldman posits that additional cases are likely to be filed in the wake of Rosetta Stone but that they are unlikely to succeed because they have less merit. See id.

99. Mark Bartholomew, Copyright, Trademark and Secondary Liability After Grokster, 32 COLUM. J.L. \& ARTS 445, 446 (2009).

100. Rosetta Stone II, 676 F.3d at 163 (internal citations and quotations omitted).

101. Hard Rock Cafe Licensing Corp. v. Concession Servs., Inc., 955 F.2d 1143 (7th Cir. 1992). 
In seeking to determine the appropriate remedy for the harm, tort law considers both policy and economic effects. Google and Rosetta Stone marshaled important policy arguments, so an additional factor needs to be considered. Contributory infringement is, as demonstrated in Part I, the statutory equivalent of contributory liability. Courts have long analyzed contributory liability by applying the least cost avoider equation to determine who should bear the cost. The least cost avoider theory has been applied in similar cases, and is well-suited to address this question. In Rosetta Stone, Google can avoid this harm most cheaply, and therefore should pay the cost of doing so.

\section{A. The Competing Policy Goals of Google and Rosetta Stone}

Google and its amici marshal four policy arguments why Google's keyword advertising policies do not infringe trademarks. First, they assert that the advertisements fund search engines, which aid the public in navigating the Internet, and therefore the value of having a search engine should outweigh the cost of the infringement. ${ }^{102}$ Second, they contend that the First Amendment protects their business practices, which promote disseminating information to consumers. ${ }^{103}$ Third, they represent that keyword advertising fosters competition between trademark owners. ${ }^{104}$ While a "small minority" of consumers may "lack ... sophistication," their confusion should not outweigh "the value that society obtains from comparative advertising, and the truthful expression of keyword advertisers who buy access to Internet users who have evinced interest in learning more about 'Rosetta Stone.' "105 Fourth, they maintain that Rosetta Stone-as the trademark owner-must police its marks: Google is not responsible for the infringing activities of its users. ${ }^{106}$

Rosetta Stone and amici disagree. They charge that Google is better positioned to fix this issue, ${ }^{107}$ that Google profits from this infringement, ${ }^{108}$

102. Corrected Brief for eBay Inc. \& Yahoo! Inc. as Amici Curiae Supporting Appellee, supra note 3 , at $* 2$.

103. Brief for Public Knowledge \& Electronic Frontier Foundation as Amici Curiae Supporting Appellee, Rosetta Stone II, 676 F.3d 144. (No. 10-2007), 2010 WL 4952558, at *21.

104. See Corrected Brief for eBay Inc. \& Yahoo! Inc. as Amici Curiae Supporting Appellee, supra note 3, at*6; Brief for Public Knowledge \& Electronic Frontier Foundation as Amici Curiae Supporting Appellee, supra note 103, at *2.

105. Brief for Public Citizen as Amicus Curiae Supporting Appellee at $* 29$, Rosetta Stone II, 676 F.3d 144 (No. 10-2007), 2010 WL 4931029.

106. Corrected Brief for eBay Inc. \& Yahoo! Inc. as Amici Curiae Supporting Appellee, supra note 3 , at $* 3$.

107. For changing the business model, see Brief for Convatec et al. as Amici Curiae Supporting Appellant, supra note 53 , at $* 22$. For policing trademarks, see Brief for Carfax et 
and that Google is in fact the only actor that can substantially keep infringement from occurring. ${ }^{109}$ Some object that if the court does not make Google change, it will continue to infringe. ${ }^{110}$ Others argue that the benefits of keyword advertising do not outweigh the damage done to trademark owners. ${ }^{111}$ Trademark law evolved-in part-to lift the burden on the consumer. If the infringement confuses or troubles consumers, then this aim is not met.

When public policy goals point to one outcome, it is tempting to make a determination of wrongdoing based on those principles alone. However, the dueling goals in this case do not lend themselves to reconciliation. Here, the twin aims of trademark law seem to reach different conclusions: protecting consumers appears to lead to a judgment in favor of Rosetta Stone, and promoting competition may lead to a judgment favoring Google.

\section{B. Why the Least Cost Avoider Equation SHOUld Be Applied}

There are many ways to attribute fault or cost in a tort case. However, not all fit every situation. This case has three actors: the injured, the injurer, and the facilitator or third party. The injured party can take steps to prevent the harm. Here, it can litigate. The injurer can take steps to prevent the harm as well, by simply not engaging in harmful activities. But where the injurers are numerous and likely judgment proof, and deterring one injurer does little to deter another, the facilitator becomes the next most plausible defendant. The injurers could not complete their activities without the help of the facilitator. As between the injured party and the facilitator, therefore, the facilitator can best avoid infringement.

When both parties can avoid the harm, courts turn to the theory of the least cost avoider and "place the burden of covering the costs of the accident on the individual who can avoid the accident at the lowest cost, no matter whether it is the injurer, the victim, or a third party."112 The theory of the least cost avoider is most commonly attributed to then-Professor (now

al. as Amici Curiae Supporting Appellant, at *21-22, 676 F.3d 144 (No. 10-2007), 2010 WL 4306014. For consumer confusion, see $i d$. at $* 22$.

108. See Brief for Convatec et al. as Amici Curiae Supporting Appellant, supra note 53, at *2-3; see also Brief for Volunteers of America, Inc. as Amici Curiae Supporting Appellant, supra note 53 , at $* 4-5$.

109. Brief for Carfax et al. as Amici Curiae Supporting Appellant, supra note 107, at *22.

110. Id. at *3.

111. See Brief for Convatec et al. as Amici Curiae Supporting Appellant, supra note 53, at *22 (arguing that "the possibility that a trademark infringer might be forced to tweak its business is not a reason to allow infringement to continue").

112. TORT LAW AND ECONOMICS (ENCYClOPEDIA OF LAW AND ECONOMICS) 16 (Michael G. Faure, ed., 2009). 
Judge) Guido Calabresi, in his 1970 work The Cost of Accidents. ${ }^{113}$ He argued that in cases where both parties can prevent an accident, the party that could have prevented the accident most cheaply should be found to be the party at fault. ${ }^{114}$ This future-focused approach encourages actors to avoid accidents as best they can, thereby hopefully resulting in fewer accidents. ${ }^{115}$ Although online contributory trademark infringement differs from real-world accidents, in both situations, both injured and injurer can prevent the harm from taking place.

Such an approach in trademark infringement is not new, particularly in the realm of new technology: the Second Circuit followed it in Tiffany. ${ }^{116}$ After a lengthy bench trial, ${ }^{117}$ the Second Circuit evaluated the multiple programs, systems, and policies that eBay had created to help intellectual property rights owners protect their brands, products, and trademarks. ${ }^{118}$ For buyers, eBay created buyer protection programs, where eBay would reimburse customers who purchased counterfeit goods. ${ }^{119}$ For brand owners, eBay created a notice-and-takedown system called the "Verified Rights Owner" program that permits rights owners to report potentially infringing listings to eBay, who would then review and delete the listings. ${ }^{120}$ eBay also allowed rights owners to create "About Me" pages to communicate directly with eBay users, and to review and flag advertisements for infringement by delaying buyers' ability to view certain brand listings for six to twelve hours and restricting other types of actions. ${ }^{121}$ Internally, eBay established a "Trust and Safety" department of 4,000 employees to monitor a "fraud engine" that identifies illegal listings and uses filters not only to find more subtle

113. Guido Calabresi, The Cost of Accidents: A Legal and Economic ANALYSIS (1970).

114. Judge Calabresi and his co-author, Douglas Melamed, sum the approach up neatly in Property Rules, Liability Rules, And Inalienability: One View Of The Cathedral, 85 HARV. L. REV. 1089, 1096-97 (1972) They state:

$[1] \mathrm{n}$ particular contexts ... this suggests putting costs on the party or activity which can most cheaply avoid them ... that in the absence of certainty as to who that party or activity is, the costs should be put on the party or activity which can with the lowest transaction costs act in the market to correct an error in entitlements by inducing the party who can avoid social costs most cheaply to do so ....

Id.

115. TORT LAW AND ECONOMICS, supra note 112, at 84.

116. See Tiffany Inc. v. eBay Inc., 600 F.3d 93, 98-100 (2d Cir. 2010).

117. Rosetta Stone II, 676 F.3d 144, 165 (4th Cir. 2012).

118. Tiffany, 600 F.3d at 99.

119. Id.

120. Id.

121. Id. 
advertisements but also Tiffany-specific filters; attached special warning messages when seller attempted to list a Tiffany item and flagged such the listings for review if ultimately posted; and suspended sellers who were suspected of engaging in infringing conduct. ${ }^{122}$ Although eBay technically controls its website, it did not have perfect control of user-generated content. However, it had tools to identify fraudulent products. Despite the extent of effort that eBay had put into keeping the site free from fraudulent products, Tiffany claimed that it would be impossible for eBay to know if it sold counterfeit items unless it ceased to feature Tiffany products altogether. The district court decided that Tiffany did not have the right to control the entire secondhand market for its products, regardless of the amount of counterfeit items on the market. ${ }^{123}$ Because eBay appeared to have done all that it could to identify fraudulent postings_-short of ceasing sale of all Tiffany merchandise on its website - the district court found that eBay did not fulfill the "knows or has reason to know" prong of the Inwood Labs test. Thus, eBay was not liable for contributory trademark infringement. ${ }^{124}$

Despite the substantial amount of energy and resources that eBay expended, eBay remained the least cost avoider in creating backend technology to prevent the infringement in the future. As expensive as it was for eBay, if Tiffany were to dedicate a department to search for infringing listings, purchase all goods that purported to be Tiffany products, or create computer software that would search for infringing listings, the cost would be astronomical. Without help from eBay, Tiffany can do little more than identify the offending listings: it cannot block consumers from seeing such listings, block users from uploading these listings, or identify the listings before they go online. Placing Tiffany as the bearer of the technology burden would waste effort and resources. However, Tiffany remains the best evaluator of counterfeit items. eBay does not have sufficient expertise in Tiffany goods, nor any other branded goods, to correctly identify products that are counterfeit or genuine. The cost for eBay of retaining an expert on each brand that might be listed for sale on eBay's website would be equally disproportionate to the harms that Rosetta Stone suffered. Therefore, the Court split the burden between the two-each company shouldering the burden it was best able to bear.

Google and Rosetta Stone are in a similar position to eBay and Tiffany. The trademark owner desires the immediate and permanent cessation of all

122. Id.

123. Id. at 97. The Second Circuit rejected Tiffany's in-house study about the percentage of fraudulent postings as unscientific.

124. Id. at 109 . 
use of its trademark. The injurers are numerous and uneconomical to track down. The third party exercises some control over the website, but leaves much to the user. As in Tiffany, there are two choices. Either Google can change its trademark policies in its advertising program, or Rosetta Stone can dedicate a squad of employees to track down infringing advertisements and outbid all other advertisers for all of its trademarks.

\section{Rosetta Stone V. Google: A Least Cost Avoider Analysis}

Like eBay, Google has at least a nominal amount of power in this situation, and is best suited to solve this problem. First, Google has the capability to fix this issue as the sole owner and manager of its AdWords program. Second, Google has fixed similar problems before: Google made changes to its copyright policy and has been unofficially evolving its trademark policy. Third, Google is the least cost avoider: Rosetta Stone is far less equipped to patrol and fix these issues. There are several strategies within Google's control that could mitigate trademark infringement. The least cost avoider analysis leads to an unambiguous conclusion: Google can fix this problem, has fixed this problem, and should fix this problem.

\section{Google Can Fix This Problem}

As the creator, owner, and manager of the AdWords program, Google has sole control over the advertisements that are placed. Google screens these advertisements using a computer program and in some instances a person. ${ }^{125}$ The entire process takes place in-house once an advertiser has submitted an ad. Google can remove the advertisements at any time. ${ }^{126}$ Google's policies delineate specific guidelines with which advertisers must conform. ${ }^{127}$ Rosetta Stone, on the other hand, had no insight or input into Google's processes until filing its complaint and reaching discovery, because Google's information is propriety and subject to protective order. ${ }^{128}$ Currently, Rosetta Stone's only opportunity to comment, complain, or

125. Interview with former advertising employee, Google, in Berkeley, Cal. (Dec. 14, 2012).

126. See Help for Trademark Owners, GOOGLE ADvertising POLICIES, https://support. google.com/adwordspolicy/answer/2562124?hl=en\&ref_topic=1346940 (last visited Mar. 11, 2013) (explaining that trademark owners may file complaints over trademarks used in AdWords advertisements, which implies that Google retains the ultimate control over removing an advertisement).

127. AdWords Policy Center, Google Advertising Policies, https://support. google.com/adwordspolicy/answer/1316548? rd=1 (last visited Mar. 11, 2013).

128. In fact, not even this author was able to learn more about Google's policies than what was publically available, despite contacting a number of Google employers. The records at trial were sealed. 
otherwise engage with Google regarding any infringing advertisements occurs after an advertisement has been placed online. For Rosetta Stone to conform with Google's assertion of proper mark policing, it would need to dedicate significant resources to constantly searching for infringing advertisements. After identifying the advertisements, Rosetta Stone would then need to notify Google. Even then, its comments would only receive as much attention as Google wanted to give.

\section{Google Has Fixed This Problem}

Google has fixed this problem before. Until August 2012, Google's search algorithm completely ignored the legal nature of a website's media content: whether it was properly licensed, owned, or if it infringed the owner's copyright. ${ }^{129}$ As a result of pressure from the entertainment industry, Google announced that it would begin to factor into its search engine algorithm legitimate takedown notices filed by copyright owners. ${ }^{130}$ Further, Google refuses to advertise certain products entirely, such as tobacco, and has successfully avoided having those advertisements appear. ${ }^{131}$

Google has begun to change the way that it triggers and displays advertisements. Rosetta Stone's complaint specifically described not only the display of the advertisements but also described Google's policy and how it was enforced. ${ }^{132}$ However, the complaint no longer accurately reflects the current state of the AdWords system. There are, today, far fewer-if anyadvertisements when a person searches for a trademarked term. ${ }^{133}$ Google claims that it has not changed its trademark policy but only reorganized it for a more comprehensive understanding. ${ }^{134}$ This assertion is at odds with the reality of search results. The change in the number of advertisements displayed when a trademark is searched extends to arbitrary trademarks such as Lululemon and bumble and bumble, to some suggestive marks such as

129. Amy Chozick, Under Copyright Pressure, Google to Alter Search Results, N.Y. TIMES' Media Decoder Blog (Aug. 12, 2012, 06:58 PM), http://mediadecoder.blogs.nytimes.com/ 2012/08/10/google-to-alter-search-results-to-reflect-a-sites-history-of-copyright-infringement/.

130. See id:; see also Julianne Pepitone, SOPA explained: What it is and why it matters, CNNMONEY (Jan. 20, 2012, 12:44 PM), http://money.cnn.com/2012/01/17/technology/ sopa_explained/index.htm.

131. See Tobacco products, GoOgLe AdverTising PoliCiEs, http://support.google.com/ adwordspolicy/bin/answer.py?hl=en\&answer $=176038 \&$ topic $=1310883 \& \mathrm{ctx}=$ topic $\quad$ (last visited Feb. 23, 2013).

132. First Amended Complaint, supra note 54, at $\uparrow \uparrow 28,31,51,52$.

133. This author documented this change as early as September 2012.

134. See AdWords Trademark Policy, GoOgLe Advertising Policies, http://support. google.com/adwordspolicy $/$ bin $/$ answer.py?hl=en\&answer=6118\&topic $=1346940 \& \mathrm{ctx}=$ top ic (last visited Oct. 23, 2012). 
Citibank and Mustang, ${ }^{135}$ and to descriptive marks including Books, Inc. and Radio Shack. ${ }^{136}$

The timing of the Fourth Circuit's remand in April 2012 and the settlement between Rosetta Stone and Google in November 2012 appears relevant. Although the terms of the settlement remain secret, the timing suggests that the settlement motivated changes to Google's AdWords policies. Google's specific changes imply that it has undertaken an internal least cost avoider analysis and decided that it would be better to make changes internally, following eBay's example, than to continue to have to litigate.

\section{Google Should Fix This Problem}

As explained in Section IV.B, supra, the least cost avoider is the appropriate analysis for this case and for others like it. Google and eBay provide valuable commodities. Because much of their content consists of user-generated material, they do not have perfect control over what users post. To hold these innovative companies strictly liable for the harms caused by their users' actions would unfairly penalize them and deter them from doing business. This result is undesirable. Courts should encourage innovative companies_-such as Google-to act responsibly towards trademarks, without overly discouraging their business models. The least cost avoider theory evaluates how both parties might prevent the same harm from taking place. Because, in this case, Google is best positioned to avoid trademark infringement in keyword advertising in the cheapest manner, Google should bear the responsibility to fix this problem. There are several ways that Google might do so.

Google could reverse the changes that it made to its AdWords policy in 2004 and 2009. The 2004 policy permitted non-trademark owners to purchase trademarked terms as triggers. ${ }^{137}$ The 2009 policy permitted nontrademark owners to use trademarked terms in the text of their advertisements. ${ }^{138}$ Reversing the 2004 policy would be more effective for two reasons. First, it would remove any advertisements from being displayed when a trademarked term was searched. This would solve Rosetta Stone's concern over "efforts by certain companies to free ride on Rosetta Stone's

135. This does apply to all suggestive marks. For instance, "playboy" returned one other advertisement that did not seem to be owned by Playboy Enterprises.

136. This author documented this change as early as September 2012, by conducting these and other searches on Google. These results reflect the author's personal experimentation.

137. Rosetta Stone II, 676 F.3d 144, 151 (4th Cir. 2012).

138. Id. 
brand," as well as remove "[m]arks or terms confusingly similar to those marks." 139 Second, if a consumer were savvy enough to type in the specific trademarked term, then only Rosetta Stone advertisements would appear. Less sophisticated consumers would need to surf through the advertisements. This would permit comparative advertising and other legal uses of trademarks while recognizing Rosetta Stone's trademark ownership. Trademark owners would not held hostage by Google and forced to bid on their own marks. The decline in revenue in advertising sales might be costly in the short term, but it stands to reason that the advertisers who previously bought trademarked terms as triggers will remain interested in advertising through AdWords. ${ }^{140}$ Advertisers would simply be bidding on different terms. Google could also set a threshold price for trademark owners, using criteria such as similar triggers, their other advertisements, or the likelihood that the search would occur. Then trademark owners that wanted to purchase their own trademarks as triggers would do so at a fair value for Google, and trademark owners that did not want to purchase advertising would not feel forced to do so.

Reversing the 2009 policy without including some review goes too far in the opposite direction. The policy illustrates that Google was already careful about trademark use in text. As the Fourth Circuit explained,

In 2009, Google changed its policy to permit the limited use of trademarks in advertising text in four situations: (1) the sponsor is a reseller of a genuine trademarked product; (2) the sponsor makes or sells component parts for a trademarked product; (3) the sponsor offers compatible parts or goods for use with the trademarked product; or (4) the sponsor provides information about or reviews a trademarked product. Google's policy shift came after it developed the technology to automatically check the linked websites to determine if the sponsor's use of the trademark in the ad text was legitimate. ${ }^{141}$

Rejecting any advertisement that uses any trademarked term would grant trademark owners far more control than the law currently allows. Fair use permits the use of trademarked terms in advertisements of non-trademark

139. First Amended Complaint, supra note 54, ๆๆ 2, 5.

140. Internet advertising strategies focus on the number of impressions (the number of times the ad is shown on a page). The higher the number of impressions, the more likely the consumer will remember the product. Bidding on one's own mark increases consumer exposure to the mark through both organic and paid search results, and therefore provides an extra boost to brand recognition.

141. Rosetta Stone II, 676 F.3d at 151-52. 
owners. To ban them completely would grant trademark owners an unequal amount of power.

One way to strike a balance that incorporates fair use concerns would be to implement a program similar to that of eBay. It seems that a similar program for advertisement text review would be beneficial. Google could set up a tool that automatically sends any ad containing the text "Rosetta Stone" to Rosetta Stone. Then, Rosetta Stone could review each ad and make its objections to Google before the ad was posted online. If Google then reviewed the flagged ad and disagreed with Rosetta Stone, they could follow a mutually agreeable procedure to resolve the issue. This solution is more laborious but places the bulk of the work of identifying infringing advertisements on Rosetta Stone. This makes sense since Rosetta Stone has a greater interest in policing the use of its mark than Google does.

According to one former Google employee, Google has a similar system for copyright concerns, though it is not often used. ${ }^{142}$ The changes in trademark use, though not reflected by changes to Google's official policy, likely reflect Google's increasing ability to discover infringing uses. ${ }^{143}$ These changes are at odds with Google's assertions in court. Google's changes, perhaps, reflect an internal evaluation along the lines of the least cost avoider, and Google's recognition that it can avoid these harms. If so, Google's behavior conforms to what it has done in the realm of copyright. This approach illustrates that Google is becoming a partner-not an adversaryto trademark owners. It is good for Google, and good for Rosetta Stone.

\section{SOLVING THE NEXT PUZZLE}

The least cost avoider analysis points to Google as the party responsible for avoiding trademark infringement in Rosetta Stone. Google controls the entire process by which keyword advertising takes place. While implementing review processes and filters may strain Google's current business model, Rosetta Stone cannot take action until the trademark infringement has occurred. Only Rosetta Stone can determine which uses of its trademark are appropriate and which are infringing. However, only Google can create the backend technology to prevent infringement from happening. Creating this technology would take significant resources, as seen through eBay's example, but the alternative is untenable. If eBay-a company whose revenue averaged over two billion dollars per quarter the year of the case decision-can afford to implement the strategies mentioned earlier, then Google-whose revenue

142. See supra note 125 .

143. Id. 
averaged well over ten billion dollars per quarter this year-certainly can afford to do so. ${ }^{144}$

This Note suggests that the least cost avoider is the appropriate analysis for contributory trademark infringement in evolving technologies. This Note's conclusions should not be extended to mean that Google should always be found liable in contributory trademark infringement cases. Instead, courts should apply the least cost avoider analysis to the individual facts of each case. Practically speaking, in keyword advertising cases regarding contributory trademark infringement, Google may be the least cost avoider in terms of creating the backend technology to identify trademark use in AdWords. However, the rapid rate of change in Internet use, experience, and technology may cause the next wave of advertising technology to require trademark owners to change their way of doing business. Looking to case law about previous trademark law decisions on the Internet has resulted in a body of law that is complex and unwieldy. The least cost avoider analysis provides the best solution.

144. See eBay Revenue Quarterly, YCHARTS.COM, http://ycharts.com/companies/EBAY/ revenues (last visited Jan. 23, 2013); Google Revenue Quarterly, YCHARTS.COM, http:/ ycharts.com/ companies/GOOG/revenues (last visited Jan. 23, 2013). 
